Taxonomy and systematics

\title{
A new species of Neoechinorhynchus (Eoacanthocephala: Neoechinorhynchidae) from the freshwater fish Ageneiosus inermis (Siluriformes) in the Brazilian Amazon
}

\section{Una especie nueva de Neoechinorhynchus (Eoacanthocephala: Neoechinorhynchidae) del pez dulceacuícola Ageneiosus inermis (Siluriformes) en el Amazonas brasileño}

\author{
Daniel Brito-Porto*, Amanda Karen Silva-de Souza, José Celso de Oliveira-Malta

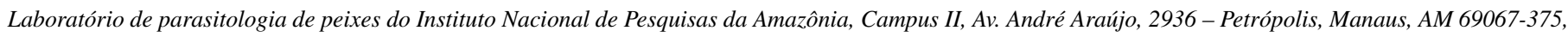 \\ Brazil
}

Received 23 September 2016; accepted 24 July 2017

Available online 28 November 2017

\begin{abstract}
This work describes a new species of the genus Neoechinorhynchus, a parasite found in the Siluriformes fish, Ageneiosus inermis collected in Catalão Lake. This species is most closely related to $N$. (N.) pterodorides and N. (N.) pimelodis than other species registered in Brazil. The size of its trunk, hooks and male reproductive system distinguish it from these 2 species. This work contributes to increase the knowledge of the biodiversity of fish parasites in the Amazon.

(C) 2017 Universidad Nacional Autónoma de México, Instituto de Biología. This is an open access article under the CC BY-NC-ND license (http://creativecommons.org/licenses/by-nc-nd/4.0/).

Keywords: Fish parasite; Ageneiosus inermis; Solimões and Negro rivers; Catalão Lake; Amazon

\section{Resumen}

En este trabajo se describe una nueva especie del género Neoechinorhynchus, un parásito del pez Ageneiosus inermis (Siluriformes), recolectado en el lago Catalão. Esta especie está más estrechamente relacionada con $N$. (N.) pterodorides y $N$. ( N.) pimelodis que otras especies de Neoechinorhynchus registradas en Brasil. El tamaño del tronco, los ganchos y el sistema reproductor masculino son los caracteres que la distinguen de estas 2 especies. Este trabajo contribuye al conocimiento de la biodiversidad de los parásitos de los peces en el Amazonas.

(C) 2017 Universidad Nacional Autónoma de México, Instituto de Biología. Este es un artículo Open Access bajo la licencia CC BY-NC-ND (http://creativecommons.org/licenses/by-nc-nd/4.0/).
\end{abstract}

Palabras clave: Parásito de peces; Ageneiosus inermis; Ríos Solimões y Negro; Lago Catalão; Amazonas

\section{Introduction}

The phylum Acanthocephala is a poorly known helminth group in Neotropical fishes. The composition of the known acanthocephalan fauna shows that the Neoechinorhychidae is

\footnotetext{
* Corresponding author.

E-mail address: danielbporto81 @gmail.com (D. Brito-Porto).

Peer Review under the responsibility of Universidad Nacional Autónoma de México.
}

the family most represented (Santos, Gibson, Tavares, \& Luque, 2008). In Brazil few species are known from this genus. Of the 109 species described as belonging to the genus Neoechinorhynchus Stiles \& Hassall, 1905, 7 are relegated to other genera, 14 are considered invalid, 11 belong to the subgenus Hebesoma, 48 belong to the subgenus Neoechinorhynchus and 29 are retained as valid but cannot be assigned to any subgenus (Amin, 2002).

In Brazil, only 7 species have been described thus far. This study describes a new species of Neoechinorhynchus a parasite 

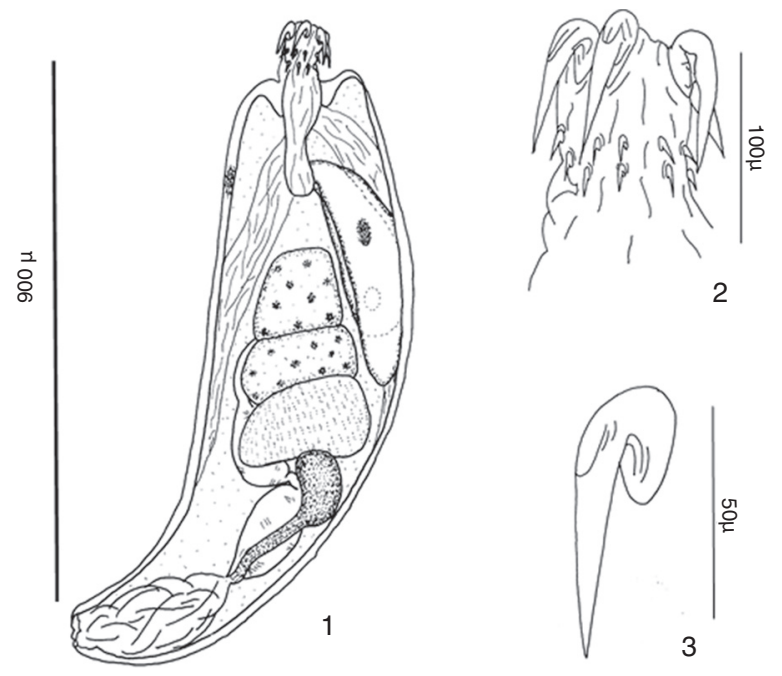

Figures 1-3. 1, Neoechinorhynchus inermis sp. n., male; 2, proboscis; 3, thorn.

of Ageneiosus inermis, collected from a floodplain lake in the Amazon.

\section{Materials and methods}

The fish were collected from the Catalão Lake, a fluviallacustrine system at the confluence of the Negro and Solimões rivers $\left(03^{\circ} 10^{\prime} 04^{\prime \prime} \mathrm{S}, 59^{\circ} 54^{\prime} 45^{\prime \prime} \mathrm{W}\right)$ during the flood period in May 2015. The fish were necropsied in the field and their bodies were fixed, labeled and analyzed in the Laboratory of Fish Parasitology at the National Institute for Amazonian Research (INPA). The specimens were then fixed in $70 \%$ ethanol for processing. Worms stained in regressive staining techniques (Carmin alcoholic) according to Amato, Boeger, and Amato (1991), and cleared in immersion oil and mounted in Canada balsam. Drawings were made with the assistance of a lightfield Olympus BH-2 microscope. All measurements are in micrometers $(\mu \mathrm{m})$. Ecological parameters follow Bush, Lafferty, Lotz, and Shostak (1997). Holotype and paratypes were deposited in the Non-insect Invertebrate Collection of the Instituto Nacional de Pesquisas da Amazônia-INPA.

\section{Description}

Neoechinorhynchus (Neoechinorhynchus) inermis n. sp.

(Figs. 1-3)

General. With characters of the genus and subgenus Neoechinorhynchus. Elliptical or ovoid body, smooth and rough edges. Neck visible and well developed. Proboscis globular, with 18 hooks distributed in 3 rows of 6 hooks. Larger anterior hooks. Proboscis sheath with simple muscular layer. Central ganglion spherical and located in the proboscis sheath. 5 giant nuclei present on the dorsal side of the amebiform's trunk and 1 on the ventral side. Lemnisci of different sizes. Lacunar system with main channels situated on dorsal and ventral sides (Table 1).

Male: measurements based on 2 male specimens. Trunk length $1.836-1.296(1,556 \pm 381.4)$ and width 540. Coni- cal neck length 99-68.4 (83.7 \pm 21.9$)$ and width $82.8-54$ (68.1 \pm 19.9$)$. Proboscis length $126-99(112.5 \pm 19)$ and width $108-79.2(93 \pm 20)$. Lemniscus uninucleate length 490-210 (350 \pm 198$)$ and width $140-105(122.5 \pm 24.7)$ and binucleate with saccule format length 301-140 (220 \pm 113$)$ and width 105-98 (101.5 \pm 4.9$)$. Giant amoeboid nuclei, 5 dorsal and 1 or 2 ventral. Anterior hooks (the largest) length $133-116.2$ (124.5 \pm 12$)$ and width $14-10.5$ (12.2 \pm 2.8$)$, middle hooks length 79.4-29.4 (54 \pm 35.4$)$ and width 5.1-3.4 $(4 \pm 1.4)$ and posterior hooks 26.6-23.1 (24.8 \pm 2.1$)$ and width 2.1. Proboscis receptacle length $414-288(351 \pm 89.1)$ and width 324-198 (261 \pm 89.1$)$. Anterior testis length 246.6-198 $(222.3 \pm 33.9)$ and width $216-180(198 \pm 25.5)$. Posterior testis length 133.2-270 (201.6 \pm 96.9$)$ and width 97.2-127 $(112.1 \pm 21.2)$. Cement gland length 198-288 (243 \pm 63.6$)$ and width 369-180 (270 \pm 127.3$)$. Ovoid shaped cement reservoir length 270-180 (225 \pm 63.6) and width 118.8-108 (113 \pm 7.1$)$. Saefftigen's elongated pouch length 504-396 (450 \pm 76.4$)$ and width $127.8-126(126 \pm 0.7)$. Male reproductive system occupies $71-75 \%$ of the body length.

Female: it was not found.

\section{Taxonomic summary}

Type host: A. inermis (Linneus, 1766) Auchenipteridae, common name: Mandubé.

Type locality: Catalão Lake $\left(03^{\circ} 10^{\prime} 04^{\prime \prime} \mathrm{S}, 59^{\circ} 54^{\prime} 45^{\prime \prime} \mathrm{W}\right)$; the confluence of the Negro and Solimões rivers near Manaus city.

Specimens deposited: holotype INPA-17: non-insect Invertebrate Collection INPA; Paratipes INPA-18.

Site of infestation: upper intestine.

Prevalence: 55; mean intensity: 5.6; mean abundance: 3.1. Etymology: its name is derived from the host's name.

\section{Remarks}

In Brazil, 7 species of Neoechinorhynchus $(N$.$) have been$ registered: $N$. (N.) buttnerae Golvan, 1956; $N$. (N.) curemai Noronha, 1973; N. (N.) macronucleatus Machado Filho, 1954; N. (N.) paraguayensis Machado Filho, 1959; N. (N.) pimelodi Brasil-Sato \& Pavanelli, 1998; N. (N.) pterodoridis Thatcher, 1981 and N. (N.) veropesoi Melo et al., 2015 (Amin, 2002; Santos et al., 2008; Thatcher, 2006).

$N$. (N.) buttnerae; $N$. (N.) pterodoridis; $N$. (N.) veropesoi, and $N .(N)$ curemai have been registered in the Amazon region (Martins, Fujimoto, Andrade, \& Tavares-Dias, 2000; Noronha, 1984; Santos et al., 2008; Thatcher, 2006).

Thatcher (1981) outlines the characteristics that distinguish $N$. pterodoridis from other species: (1) neck long and visible, (2) anterior, middle and posterior circles of hooks larger than in other species. This species was compared with $N$. paraguayensis and N. golvani Salgado-Maldonado, 1978.

Brasil-Sato and Pavanelli (1998) distinguish N. pimelodis from the 8 species of Acanthocephala registered in Brazil: $N$. $(N$.) buttnerae, $N$. (N.) curemai, $N$. (N.) macronucleatus, $N$. (N.) paraguayensis, $N$. (N.) pimelodi, $N$. (N.) pterodoridis, $N$. (N.) golvani Salgado-Maldonado, 1978, and $N$. (N.) villoldoi Viz- 
Table 1

Comparison between Neoechinorhyncus inermis n. sp. and other species of Neoechinorhynchus. All measurements are in micrometers. AH =anterior hook, middle hook or posterior hook; $\mathrm{Lt}=$ length trunck, $\mathrm{Gc}=$ cement gland, $\mathrm{Si}=$ site of infection.

\begin{tabular}{|c|c|c|c|c|c|}
\hline Especies/host & $\mathrm{AH}, \mathrm{MH}, \mathrm{PH}$ & $\mathrm{Ct}$ (trunk) & Gc & SI & Distribution \\
\hline \multicolumn{6}{|c|}{$N$. (N.) inermis/Ageneiosus inermis } \\
\hline Male & $124.2,54,4$ & 1,556 & 243 & Upper intestine & Amazonas \\
\hline Female & No date & & & & \\
\hline \multicolumn{6}{|c|}{$N$. (N.) veropesoi/Plagiosciom squamosissimus } \\
\hline Male & $67.9,22.2,12$ & 2,800 & 203.6 & Small intestine & Pará - Guajará Bay \\
\hline Female & $87.1,25.5,13.8$ & 5,870 & & & \\
\hline \multicolumn{6}{|c|}{ N. (N.) pterodoridis/Pterodoras granulosus } \\
\hline Male & $143,45,10$ & 2,250 & 336 & Intestine & Amazonas \\
\hline Female & $139,39,12$ & 2,700 & & & \\
\hline \multicolumn{6}{|c|}{ N. (N.) pimelodi/Pimelodus maculatus } \\
\hline Male & $105,36,23$ & 1,450 & 162 & Anterior intestine & Mato Grosso - São Francisco River \\
\hline Female & $129,47,29$ & 2,440 & & & \\
\hline
\end{tabular}

cain, 1992. N. pimelodis is shown to be most closely related to $N$. (N.) pterodoridis Thatcher, 1981. Of the species that occur in Brazil, this new species described here is most similar to $N$. (N.) pterodoridis and $N$. (N.) pimelodis.

$N$. (N.) inermes sp. n. shows most similarity to $N$. (N.) pterodoridis collected from the Amazonas River (Thatcher, 1981) and $N$. (N.) pimelodis collected from the São Francisco River (Brasil-Sato \& Pavanelli, 1998). It is distinguished from $N$. (N.) pterodoridis with smaller trunk length, and from $N$. (N.) pimelodis with greater trunk length.

The proboscis of $N$. (N.) inermes sp. n. is smaller than that of $N$. (N.) pterodoridis and approximately the same size as that of $N$. (N.) pimelodis. Its neck is much smaller than the necks of both other species. The lemnisci are also much smaller. The male reproductive system occupies $75 \%$ of its cavity which is larger than in both $N$. (N.) pterodorides $(73 \%)$ and $N$. (N.) pimelodi $(50.73 \%)$.

The anterior and medium hooks of $N$. (N.) inermes sp. n. are smaller than those of $N$. (N.) pterodoridis and larger than those of $N$. (N.) pimelodis. The posterior hooks are of similar size as $N$. (N.) pimelodis. Anterior testis is smaller compared to the other species and the posterior testis is smaller than that of $N$. (N.) pterodoridis and larger than that of $N$. (N.) pimelodis.

The cement gland of $N$. (N.) inermes sp. n. is smaller than that of $N$. (N.) pterodoridis and larger than that of $N$. (N.) pimelodis. The cement reservoir is larger than those of both other species. Morphological study presents similarities between the anatomy of the $N$. (N.) inermes sp. n. and both $N$. (N.) pterodoridis and $N$. (N.) pimelodis, but it is distinguished by significant differences in the main organs of these 2 species.

Based on these characteristics, the present work describes the first species of the genus parasitizing $A$. inermis, the eighth species of the genus described from Brazil. Thus, the present work contributes to the knowledge of Brazilian parasites by adding a new species and new host for the genus Neoechinorhynchus.

\section{References}

Amato, J. F. R., Boeger, W. A., \& Amato, S. B. (1991). Protocolos para laboratório-coleta e processamento de parasitas do pescado. Rio de Janeiro: Imprensa Universitária, Universidade Federal do Rio de Janeiro.

Amin, O. M. (2002). Revision of Neoechinorhynchus Stiles \& Hassal, 1905 (Acanthocephala: Neoechinorhynchidae) with Keys to 88 species in two subgenera. Systematic Parasitology, 53, 1-18.

Brasil-Sato, M. C., \& Pavanelli, G. C. (1998). Neoechinorhynchus pimelodi sp. n. (Eoacanthocephala, Neoechinorhynchidae) parasitizing Pimelodus maculatus Lacépede, "mandi-amarelo" (Siluroidei, Pimelodidae) from the basin of the São Francisco River, Três Marias, Minas Gerais, Brazil. Revista Brasileira de Zoologia, 15, 1003-1011.

Bush, A. O., Lafferty, K. D., Lotz, J. M., \& Shostak, A. W. (1997). Parasitology meets ecology on its own terms: Margolis et al Revisited. American Society of parasitologists. The Journal of Parasitology, 83, 574-583.

Martins, M. L., Fujimoto, R. Y., Andrade, P. M., \& Tavares-Dias, M. (2000) Recent studies on Neoechinorhynchus curemai Noronha, 1973 (Acanthocephala: Neoechinorhynchidae). In Prochilodus Lineatus Valenciennes, 1836, From Volta Grande reservoir, MG, Brazil. Revista Brasileira de Biologia, 60, 673-682.

Noronha, D. (1984). Remarcks on Neoechinorhynchus curemai Noronha, 1973 (Eoacanthocephala: Neoechinorhynchidae). Memórias do Instiuto Oswaldo Cruz, 79, 271 .

Salgado-Maldonado, G. (1978). Acantocéfalos de peces IV. Descripcion de dos especies nuevas de Neoechinorhynchus Hamann, 1892 (Acanthocephala: Neoechinorhynchidae) y algunas consideraciones sobre este género. Anales del Instituto de Biología, Universidad Nacional Autónoma de México, Serie Zoología, 49, 35-48.

Santos, C. P., Gibson, D. I., Tavares, L. E. R., \& Luque, J. L. (2008). Checklist of Acanthocephala associated with the fishes of Brazil. Zootaxa, 1983, 1-22.

Thatcher, V. E. (1981). Neoechinorhynchus pterodoridis n. sp. (Acanthocephala: Neoechinorhynchidae) do bacu liso (Pterodoras granulosus) da Amazônia Brasileira. Acta Amazonica, 11, 445-448.

Thatcher, V. E. (2006). Amazon fish parasites (2a Ed.). Moscow: Editora Aquatic Biodiversity in Latin America. 